\title{
Matematiksel Modelleme İle İlgili Lisansüstü Tezlerin Tematik Içerik Analizi
}

\author{
Şafak YILDIZ, Kürşat YENILMEZ*
}

Matematiksel Modelleme Ille Illgili Lisansüstü Tezlerin Tematik İçerik Analizi

Özet

Bu çalışmanın amacı matematiksel modelleme ile ilgili lisansüstü tezleri incelemektir. Çalışmada nitel araştırma yöntemlerinden tematik içerik analizi modeli kullanıımıştı. Araştırmanın çalışma grubu 2000-2017 yılları arasında matematiksel modelleme ile ilgili hazırlanan 48 tezden oluşmaktadır. Araştırma sonucunda matematiksel modelleme ile ilgili tezlerin daha çok matematik öğretmenliği ve ilköğretim matematik öğretmenliği alanlarında yapıldığı, matematiksel modellemenin ülkemizde 2005 yılından sonra ilgi görmeye başladığı belirlenmiş̧ir. Çalışmalar daha çok ortaokul öğrencileri ve öğretmen adayları üzerinde yapılmış ve nitel ve karma yöntemler çoğunlukla tercih edilmiştir. Çalışmalarda model olarak durum çalışması ve deneysel desenlerin kullanıldı̆ı, veri analizinde içerik analizi ve betimsel analizin kullanıldığı belirlenmiştir. Verilerin çoğunlukla görüşme, video/ses kaydı ve testlerle toplandığı görülmektedir. Tezlerde çalışılan konuların daha çok problem çözme ve modellemeye ilişkin görüşlerin tespit edilmesi şeklinde olduğu belirlenmiştir.

Anahtar Kelimeler: İçerik Analizi, Matematik Eğitimi, Matematiksel Modelleme
Thematic Content Analysis Of Graduate Theses Related to Mathematical Modelling

\section{Abstract}

The aim of this study is to examine the graduate theses about mathematical modeling. Thematic content analysis model was used in the study. 48 theses were obtained in period of 2000 and 2017. As a result of the study, it was determined that mathematical modeling studies were mostly carried out in the fields of mathematics teaching and elementary mathematics teaching, and mathematical modeling started to attract interest in our country after 2005 . Studies have mostly been done on middle school students and pre-service teachers and qualitative and mixed methods are mostly preferred. In the studies, it was determined that the case study and experimental designs were used as a model, content analysis and descriptive analysis were used in data analysis. It is seen that the data is mostly collected by interview, video / voice recording and tests. It was determined that the subjects studied in the theses were more problem solving and modeling views.

Key Words: Mathematical Modeling, Mathematics Education, Content Analysis

\section{Giriş}

Öğrencilerin matematik eğitiminde en çok zorlandıkları konulardan birisi verilen problemleri anlayamamaları, gerçek dünya problemi ile matematik dünyası arasındaki ilişkiyi kuramamalarıdır.

* Kürşat YENILMEZ, Prof. Dr., Eskişehir Osmangazi Üniversitesi, Eğitim Fakültesi, kyenilmez@ogu.edu.tr, ORCID ID orcid.org/0000-0001-6256-4686, Şafak YILDIZ, Alaşehir Şehit Evren Kara MTAL, safakyildiz@windowslive.com, ORCID ID orcid.org/0000-0001-5372-3526 
Şafak YILDIZ | Kürşat YENILMEZ

Bu yüzden verilen problemleri çözmekte zorlanabilmektedirler. Öğrencilerin problemleri çözebilmeleri için farklı yöntemler kullanarak soyut olan ifadeleri somut hale getirmeleri gerekmektedir. Öğrenciler somut olarak ifade edilen problemleri, daha kolay anlayabilirler ve çözüme ulaştırabilirler. Verilen bir sözel problemi zihninde canlandırarak çözüme ulaştırabilen çok az insan var iken görsel hale getirilmiş bir problemi çözebilecek daha fazla kişi olabilir. Problemlerin görsel olarak ifade edilmesi problemi ilgi çekici hale getirebilir, öğrencileri derse motive edebilir ve öğrencileri problemi çözmeye teşvik edebiliriz. Öğrencilerin karşılaştıkları problemleri matematiksel olarak bir sonuca ulaştırmaları yeterli değildir. Bu sonuçları yorumlamaları, gerçek problemle ilişkilerini kurabilmeleri, benzer problemlerin nasıl sonuçlar doğurabileceğini tahmin etmeleri gerekmektedir. Öğrenciler verilen sözel problemleri aynı yöntemle çözebilirler. Fakat öğrencilerden, aynı yöntemle çözdükleri problemlerin sonuçlarını, gerçek hayattaki karşılıklarını düşünerek yorumlamaları beklenmektedir. Aşağıda verilen iki sözel problemi düşünelim. Dedeleri Kathy, Ingrid, Hansand,Tom eşit miktarda paylaşmaları için 14 parçadan oluşan bir kutu çikolata aldı. Her çocuğun kaç tane çikolata parçası alacağını bulunuz (Reusser ve Stebler, 1997). Büyükbaba 4 torununa eşit miktarda paylaşmaları için 18 adet balon verdi. Her bir torun kaç tane balon alır? (Davis, 1989 Akt:Reusserve Stebler,1997). Öğrencilerin bu iki problemi çözerken balonların bölünemeyeceğini ancak çikolataların bölünebileceğini düşünmeleri gerekmektedir. Bu problemlerin gerçek hayattaki karşılıklarını düşünmeleri ve buna göre yorumlayarak bir sonuca varmaları beklenmektedir. Özellikle sözel problemlerde, matematik dünyasıyla gerçek hayat arasında sürekli bir ilişkinin kurulması gerekmektedir.

Öğrencilerin problemleri çözmelerini kolaylaştıran yöntemlerden birisinin de matematiksel modelleme olduğu söylenebilir. Matematiksel modelleme; gerçek hayatla ilişkili matematiksel bir problemin yorumlanması daha sonra grafik, tablo, çizim, matematiksel ifadeler vb. araçlarla görselleştirilip somut hale getirilerek çözülmesi ve sonucun gerçek problemle ilişkilendirilerek çıkarımlarda bulunulmasını sağlayan matematiksel bir yöntemdir. Matematiksel modellemenin öğrencilerin yorum yapma, çıkarımda bulunda, ilişkilendirme ve farklı temsilleri kullanma becerilerini geliştirebileceği ifade edilebilir.

Matematiksel modellemenin alanyazında farklı tanımları yapılmışır. Matematiksel modelleme tanımlarına bakıldığında gerçek hayat problemlerinden yola çıkıldığı görülmektedir. Buda matematiğin insanların yaşamlarını kolaylaştırdığı, matematiğin günlük yaşamdan ayrı tutulamayacağı, günlük hayatta sürekli karşılaştığımı problemlerin ancak iyi bir matematik okuryazarı olarak çözülebileceği düşüncesinin öğrencilere kazandıııması bakımından önemli görülebilir.

Crouch ve Haines'e (2004) göre matematiksel modelleme gerçek dünya durumundan bir modele geçilmesi, bu modelle çalışılarak gerçek hayat problemlerinin anlaşılması, geliştirilmesi veya gerçek hayat probleminin çözülmesidir. Matos'e (1998) göre matematiksel modelleme öğrencilerin düşünceleri, problemleri, matematiksel ve matematiksel olmayan kavramları anlamlandırdıkları bir etkinliktir (akt: Crouch ve Haines, 2004). Fox'a (2006) göre matematiksel modelleme günlük hayattaki problemlerin doğasındaki ilişkileri görebilmeyi, aralarındaki ilişkiyi matematiksel terimleri 
kullanarak açıklayabilmeyi, sınıflandırabilmeyi, genelleyebilmeyi ve bir sonuca varabilmeyi kolaylaştıran dinamik bir yöntemdir (akt. Hıdıroğlu,2012). Verschaffel, Greer ve De Corte'ye (2002) göre ise matematiksel modelleme gerçek yaşamdaki olayları ve bunlar arasındaki ilişkileri matematik dilini kullanarak ifade etmeye çalışma ve matematiksel örüntüleri ortaya çıkarma sürecidir (akt: Erbaş, Kertil,Çetinkaya, Çakıroğlu, Alacacı ve Baş, 2014). Blum ve Niss (1991) gerçek problem durumundan matematiksel bir model oluşturan tüm süreci modelleme veya model oluşturma olarak ifade etmektedir. Cheng'e (2001) göre matematiksel modelleme, problemlere çözüm bulmaya çalışan, gerçek dünyadaki problemleri matematiksel olarak temsil eden bir süreçtir. Matematiksel modelleme, gerçek hayattaki problemlerin, çözümü için matematiksel olarak temsil edildiği bir süreçtir. Matematiksel model, (karmaşık) gerçek yaşam probleminin veya durumun matematiksel bir forma dönüştürülerek basitleştirilmesi olarak düşünülebilir. Böylece gerçek hayat problemi bir matematik problemine dönüştürülür. Matematiksel problem için bilinen teknikler kullanılarak matematiksel çözüm elde edilebilir. Bu çözüm daha sonra yorumlanarak gerçek terimlere dönüştürülür (Şekil 1).

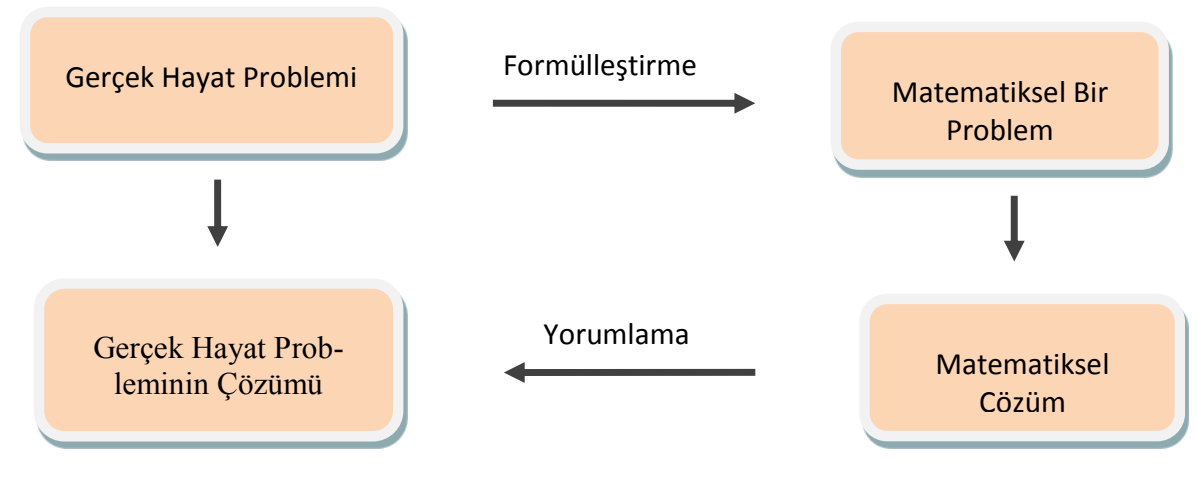

Şekil 1. Matematiksel Modelleme Süreci (Cheng, 2001)

Matematiksel modelleme, öğrencilerin gerçek hayat durumlarına ve yapılandırılmamış problemlere matematiğin uygulanmasında güven ve yeteneklerini geliştirmeyi amaçlamaktadır (Galbraith ve Clatworthy, 1990). Budinsk (2010) modellemenin amaçlarını tahmin etme, dizayn etme (tasarlama), karar vermek için olasılıkları deneme, olgunun daha iyi anlaşılmasını sağlama olarak ifade etmekte ve modelleme sırasında oluşan zihinsel aktiviteleri Şekil 2'deki gibi açıklamaktadır. 


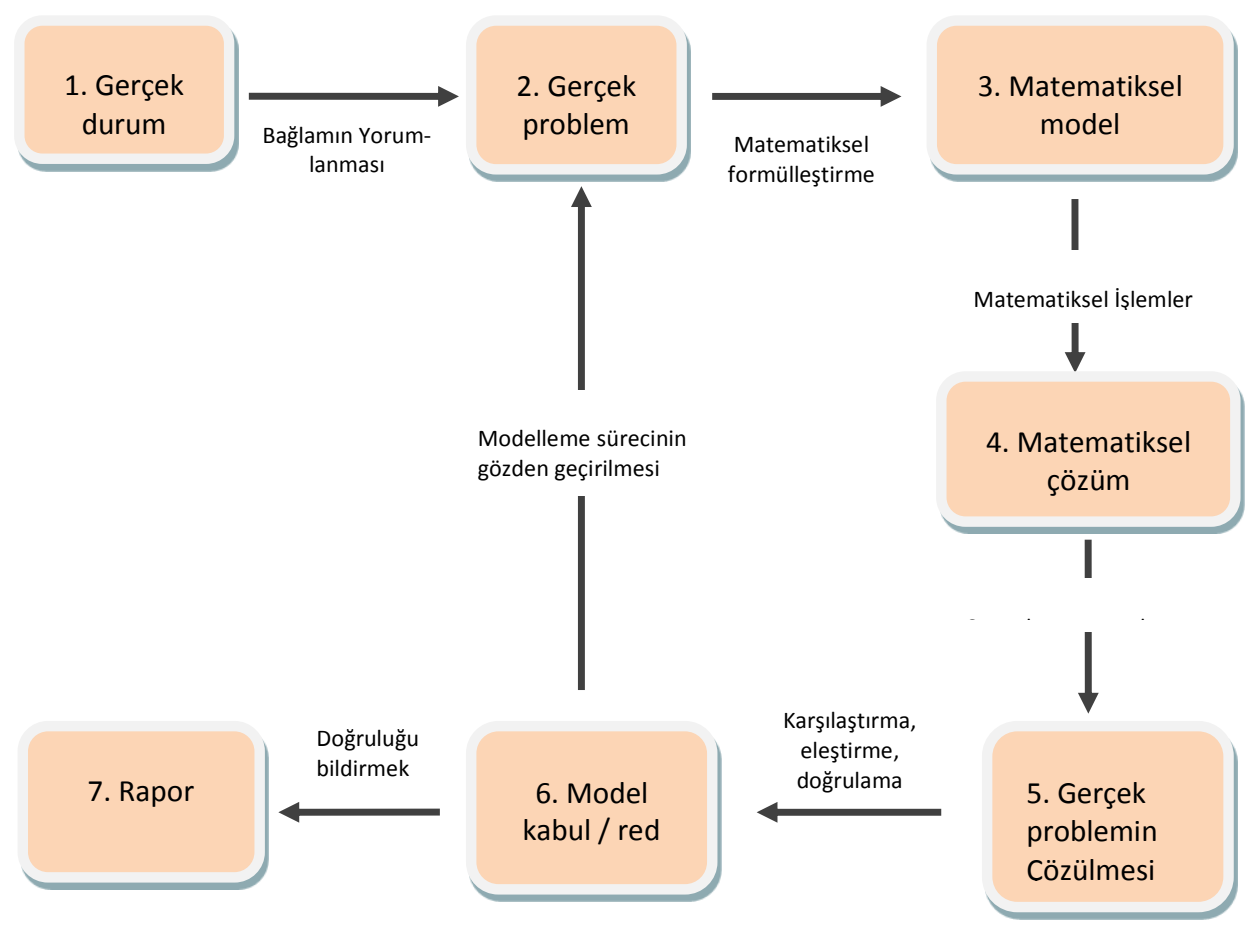

Şekil 2. Modelleme Sırasında Oluşan Zihinsel Aktiviteler (Budinsk, 2010)

Blomhøj ve Jensen (2003) matematiksel modellemeyi 6 aşamada ele almışlardır.

a) Formülleştirme görevi: modeli oluşturulacak gerçek durumun özelliklerinin tespit edilmesini sağlar.

b) Problemin amacına uygun ilişkileri, nesneleri vb. seçmek ve bunları matematiksel temsilinin oluşturulabilmesi için ideal hale getirmek.

c) Nesneleri ve ilişkileri gerçek durumundan matematiksel görünüme dönüştürmek.

d) Matematiksel sonuçlara ulaşabilmek için matematiksel yöntemlerin kullanılması.

e) Sonuçların başlangıçtaki problem alanına ilişkin olarak yorumlanması.

f) Modelin geçerliliğinin, gözlenen, öngörülen verilerle veya teorik bilgilerle karşılaştırılarak değerlendirilmesi.

Lesh ve Doerr'e (2003) göre modelleme döngüsü dört aşamadan oluşmaktadır: 
a) Tanımlama: Gerçek dünyadan modelleme dünyasına ilişkinin kurulması,

b) Uygulama: Orijinal problemin çözümü ile ilgili tahmin yapmak için modelin uygulanması,

c) Çevirme veya tahmin etme: Problemin sonuçlarının gerçek dünya ile ilişkilendirilmesi,

d) Doğrulama: Tahminlerin kullanışlıı̆̆ının incelenmesidir (akt: Özdemir ve Işık, 2015).

Ortaöğretim matematik dersi öğretim programında da (MEB, 2013) matematiksel modellemenin öğrencilerin geliştirilmesi gereken becerileri arasında yer aldığı ve matematik eğitimi açısından önemli olduğu belirtilmiştir. Söz konusu programda "matematiksel modelleme, hayatın her alanındaki problemlerin doğasındaki ilişkileri çok daha kolay görebilmemizi, matematik terimleriyle ifade edebilmemizi, sınıflandırabilmemizi, genelleyebilmemizi ve sonuç çıkarabilmemizi kolaylaştıran dinamik bir yöntemdir. Matematiksel modelleme yoluyla, öğrencilerin matematiği gerçek hayattan izole edilmiş bir disiplin olarak görme eğilimleri giderilmiş, matematiğin bir boyutunun da, gerçek hayat problemlerine modelleme yoluyla çözüm üreten sistematik bir düşünme tarzı olduğunu fark etmeleri sağlanmış olur." ifadelerine yer verilmiştir (MEB, 2013 s. Iv).

Matematiksel modellemeye ilişkin öğretmen ve öğretmen adayları üzerinde farklı çalışmalar yapılmıştır. Katı cisimlerin alan ve hacimlerinin matematiksel modelleme ile öğretimine yönelik görüşlerin belirlenmesi, matematiksel modelleme sürecini anlamayı geliştirme, modelleme ve okuduğunu anlama becerileri arasındaki ilişkiyi inceleme, model oluşturma etkinlikleri ve bu etkinliklerin matematik öğrenimine etkisi ile ilgili görüşlerin belirlenmesi çalışmaları yapılmış ve çalışmalar sonucunda öğretmenlerin matematiksel modelleme konusunda fazla bilgiye sahip olmadıkları ve derslerde fazla yer vermedikleri, öğretmen adaylarının başlangıçta modelleme konusunda başarılı olamadıkları, fakat uygulama sonucunda verilen problemleri modelleme yoluyla çözebildikleri, matematiksel modellemeyi iyi kavrayanların okuduklarını daha iyi anladıkları, model oluşturma etkinliklerinin matematik öğrenimine pozitif katkısı olduğu, ilköğretim ve diğer seviyelerde kullanılabileceği (Özdemir ve Işık, 2015; Bal ve Doğanay 2014; Ural ve Ülper, 2013; Eraslan, 2011) gibi sonuçlara ulaşılmıştır.

Alanyazında zaman zaman matematik eğitimi alanında yapılan çalışmaların değerlendirilmesinin yapıldığı tarama çalışmalarına da rastlanmaktadır. Kayhan ve Koca (2004) tarafından yapılan matematik eğitiminde araştırma konuları çalışmasının sonucunda 2000-2002 yıllarında en çok bilişsel boyut, öğretim programı ve öğretim yöntemleri konularında araştırma yapıldığı tespit edilmiştir. Güven ve Özçelik (2017) tarafından ilkokul matematik dersine yönelik hazırlanan lisansüstü eğitim tezlerinin incelendiği çalışma sonucunda en fazla çalışmanın 2007 yılında yapıldığı, tezlerde danışmanlık görevini en fazla yardımcı doçentlerin yürüttüğü gibi çeşitli sonuçlar tespit edilmiştir.

Yaşar ve Papatğa (2015) tarafından ilkokul matematik derslerine yönelik hazırlanan lisansüstü tezler çeşitli kriterlere göre incelenmiş ve çalışma sonunda daha çok yüksek lisans tezlerinin hazırlandığı, tezlerin daha çok 2010 ve 2011 yıllarında yayınlandığı, cebir alanında daha fazla tez hazırlandığı tespit edilmiştir. Ayrıca bu tezlerde, genel olarak nicel araştırma yönteminin tercih edildiği, veri toplama tekniği olarak başarı testlerinin daha fazla tercih edildiği sonuçlarına ulaşılmıştır. Yü- 


\section{Şafak YILDIZ | Kürşat YENILMEZ}

cedağ (2010) tarafından 2000-2009 yılları arasında matematik eğitimi alanında yapılan çalışmalar incelenmiş ve çalışma sonunda lisansüstü tezlerde geometri ve cebir, makalelerde ise cebir konularında daha fazla araştırma yapıldığı belirlenmiştir. Türkdoğan, Güler, Bülbül ve Danişman (2015) tarafından matematik eğitiminde kavram yanılgıları üzerine yapılan çalışmalar incelenmiş ve çalışma sonunda son zamanlarda kavram yanılgılarını tespit etmeye yönelik çalışmalarda artış olduğu fakat kavram yanılgılarını gidermeye yönelik çalışmaların sınırlı sayıda olduğu belirlenmiştir.

Gül ve Sözbilir (2015) tarafından fen ve matematik eğitimi alanında hazırlanan ölçek geliştirme çalışmaları incelenmiş ve çalışma sonunda tutumlar üzerine daha fazla çalışma yapıldığı, matematik eğitiminde daha fazla ölçek hazırlandı̆̆ı, en fazla yapı geçerliliğinin ve iç tutarlıık yöntemlerinin tercih edildiği görülmüştür. Yalçınkaya ve Özkan (2012) tarafından 2000-2011 yıllarında yayımlanan matematik öğretimi alternatif yöntemleri ile ilgili makaleler incelenmiş ve çalışma sonunda matematik öğretiminde alternatif yöntem ve teknikler ile ilgili çalışmaların en fazla 2006 yılında yapıldığı, daha çok deneysel yöntemlerin tercih edildiği, veri toplama araçları olarak daha çok test ve anketlerin kullanıldığı belirlenmiştir. Yenilmez ve Sölpük (2014) tarafından matematik dersi öğretim programı ile ilgili hazırlanan tezler incelenmiş ve çalışma sonucunda 2007 ile 2008 yıllarında 6.-8. sınıflar düzeyinde matematik öğretim programıyla ilgili öğretmen görüşlerini içeren, nicel yöntemlerin kullanıldığı çalışmaların daha fazla yapıldığı belirlenmiştir. Aztekin ve Şener (2015) tarafından Türkiye'de yapılan matematik eğitimi alanındaki matematiksel modelleme araştırmaları meta sentez (tematik içerik analizi) yöntemi ile eleştirel bir bakış açısıyla yorumlanmış ve çalışma sonunda matematiksel modelleme çalışmalarının yeterli düzeyde olmadığı, çalışmaların çoğunda durum çalışmalarının kullanıldığı tespit edilmiştir.

2017 yılında yayımlanan gerek ilköğretim gerekse ortaöğretim matematik dersi öğretim programında matematiksel modellemenin öğrencilerde matematik dersleri ile geliştirilmesi hedeflenen temel bir beceri olarak ele alınması ve son yıllarda matematiksel modelleme konusundaki araştırmaların sayısında yaşanan artışlar matematiksel modelleme konusunda yapılan çalışmaların daha güncel bir bakış açısı ile değerlendirilmesi ihtiyacını doğurmuştur. Bu çalışma sadece lisansüstü tezlere odaklanması, tezlerin bilim dallarına, veri toplama araçlarına, veri analiz yöntemlerine ve yapıldığı üniversitelere göre dağıımları ele alması bakımından Aztekin ve Şener (2015) çalışmasından farklıık göstermektedir. Bu çalışmanın amacı matematiksel modelleme ile ilgili yüksek lisans ve doktora çalışmalarının bazı değişkenlere göre incelemektir. Çalışmada matematiksel modelleme ile ilgili tezlerin,

1) Erişim durumuna göre dağılımı nasıldır?

2) Bilim dallarına göre dağıımı nasıldır?

3) Yıllara göre dağılımı nasıldır?

4) Araştırma grubuna göre dağılımı nasıldır?

5) Araştırmada kullanılan yönteme göre dağııımı nasıldır? 
6) Araştırmada kullanılan modele göre dağılımı nasıldır?

7) Veri analiz yöntemine göre dağııımı nasıldır?

8) Kullanılan veri toplama araçlarına göre dağılımı nasıldır?

9) Çalışılan konuya göre dağııımı nasıldır?

alt problemlerine cevap aranacaktır. Bu çalışmanın sonuçları; matematiksel modelleme konusunda yapılan çalışmalara yönelik daha güncel ve sistematik özet bilgiler vermesi, alanyazında konu ile ilgili eksiklikleri işaret ederek bu konuda gelecekte yapılacak çalışmalara ışık tutması bakımından önemli görülmektedir.

\section{Yöntem}

Bu çalışmada nitel araştırma yöntemlerinden doküman incelemesi modeli kullanılmıştır. Doküman incelemesi mevcut kayıt ya da belgelerin, veri kaynağı ve bunların sistemli olarak incelenmesidir (Karasar, 2016). Çalışmada modelleme ile ilgili lisansüstü tezler ortak temalar altında incelenmiş ve yorumlanmıştır. Bu yüzden çalışmada tematik içerik analizi yöntemi kullanılmıştır.

\subsection{Verilerin Toplanması}

Araştırmanın örneklemini 2000-2017 yılları arasında YÖK (Ulusal Tez Merkezi) veri tabanında yer alan matematiksel modellemeye ilişkin hazırlanan tezler oluşturmaktadır. Güncel eğilimi belirlemek için son yıllarda yapılan çalışmalar incelenmiştir. Bu yüzden 2000-2017 yılları arasında yapılan çalışmalarla sınırlı kalınmıştır. Araştırmada herhangi bir örnekleme yöntemine başvurulmamış, çalışma örnekleminin tamamına ulaşılması amaçlanmıştır. Bu çalışmada 2000 - 2017 yılları arasında Ulusal Tez Merkezi tarafından yayınlanmış olan matematiksel modellemeyle ilgili erişime açık olan 38 tez ve erişime kapalı olan 10 tez olmak üzere toplam 48 lisansüstü tez incelenmiştir (Bakınız Ek1). Tezlerin incelenmesinde daha önce yapılan çalışmalar incelenerek araştırmacılar tarafından bir form oluşturulmuştur. Araştırmadaki veriler tezin erişim durumu, tezin hazırlandığı bilim dalı, tezin yayınlandığı yıl, tezde kullanılan yöntem, araştırmanın katılımcı grubu, tezde kullanılan araştırma modeli, araştırmanın analiz yöntemleri, çalışmanın veri toplama aracı ve tezde çalışılan konu şeklinde sınıflandırılmıştır.

\subsection{Veri Analizi}

Araştırmada doküman incelemesi yöntemi kullanılarak ulaşılan tezlerin içerik analizleri yapılmıştır. İçerik analizinde yapılan temel işlem, birbirine benzeyen verileri belirli kavramlar ve temalar çerçevesinde bir araya getirmek ve okuyucunun anlayabileceği bir biçimde düzenleyerek yorumlamaktır (Yıldırım ve Şimşek, 2006). Elde edilen veriler belirlenen kriterlere göre iki uzman tarafından sınıflandırılmıştır. Analiz sonuçları karşılaştııımış farklı çıkan sonuçlarda ortak bir karar verilmiştir. İki uzmanın, cevaplarının ilgili kategorilere dağıımı konusunda görüş birliği ve görüş ayrılığı olan sorular belirlenmiş ve Miles ve Huberman (1994) tarafından önerilen, Güvenirlik = Görüş birliği / 
(Görüş birliği + Görüş ayrılı̆̆ı) formülü kullanılarak araştırmanın güvenirliği \%90 olarak hesaplanmıştır. Güvenirlik hesaplarının \%70'in üzerinde çıkması, araştırma için güvenilir Kabul edilmektedir. Analiz sonucunda elde edilen verilerin frekans dağılımları tablolar halinde sunulmuştur.

\section{Bulgular ve Yorum}

Araştırma kapsamındaki tezler erişime açık olma ve erişime kapalı olma durumlarına göre iki grupta incelenmiş ve sonuçları Tablo 1'de sunulmuştur.

Tablo 1. Tezlerin Erişim Durumuna Göre Dağııımı

\begin{tabular}{lccc}
\hline \hline \multirow{2}{*}{ Erişim Durumu } & Yüksek Lisans & Doktora & Toplam \\
\cline { 2 - 4 } & $f$ & $f$ & $f$ \\
\hline Erişime Açık & 22 & 16 & 38 \\
Erişime Kapalı & 6 & 4 & 10 \\
\hline
\end{tabular}

Tablo 1 incelendiğinde tezlerden 38 tanesinin erişime açık olduğu 10 tanesinin ise erişime kapalı olduğu görülmektedir. Yayımlanan tezlerin büyük çoğunluğunun erişime açık olduğu görülmektedir. Araştırma kapsamındaki tezler bilim dallarına göre incelenmiş ve sonuçları Tablo 2'de sunulmuştur.

Tablo 2. Tezlerin Bilim Dallarına Göre Dağıımı

\begin{tabular}{lccc}
\hline \hline & Yüksek Lisans & Doktora & Toplam \\
\cline { 2 - 4 } Bilim Dalı & $f$ & $f$ & $f$ \\
\hline Matematik Öğretmenliği & 8 & 13 & 21 \\
Illköğretim Matematik Öğretmenliği & 14 & 2 & 16 \\
Illköğretim & 3 & 3 & 6 \\
Sını Öğretmenliği & 1 & 1 & 2 \\
Fizik Öğretmenliği & 0 & 1 & 1 \\
Sistem mühendisliği & 1 & 0 & 1 \\
Belirtilmemiş & 1 & 0 & 1 \\
\hline
\end{tabular}


Tablo 2 incelendiğinde en fazla tezin matematik öğretmenliği bilim dalında yazıldığı görülmektedir. Yüksek lisansta ilköğretim matematik öğretmenliğinde, doktorada ise matematik öğretmenliğinde daha fazla tez yazıımıştır. Matematiksel modelleme ile ilgili diğer bilim dallarında da çalışma yapıldığı görülmektedir. Araştırma kapsamındaki tezler yayımlandıkları yıllara göre incelenmiş ve sonuçları Tablo 3'te sunulmuştur.

Tablo 3. Tezlerin Yıllara Göre Dağılımı

\begin{tabular}{lccc}
\hline \hline & Yüksek Lisans & Doktora & Toplam \\
\cline { 2 - 4 } Yıl & $f$ & $f$ & $f$ \\
\hline 2017 & 1 & 1 & 2 \\
2016 & 8 & 4 & 12 \\
2015 & 3 & 5 & 8 \\
2014 & 4 & 2 & 6 \\
2013 & 3 & 1 & 4 \\
2012 & 2 & 1 & 3 \\
2011 & 1 & 3 & 4 \\
2010 & 1 & 3 & 4 \\
2009 & 0 & 0 & 0 \\
2008 & 2 & 0 & 2 \\
2007 & 1 & 0 & 1 \\
2006 & 0 & 0 & 0 \\
2005 & 2 & 0 & 2 \\
2004 & 0 & 0 & 0 \\
2003 & 0 & 0 & 0 \\
\hline
\end{tabular}

Tablo 3 incelendiğinde modelleme konusunda en fazla tezin 2016 yılında yazıldığı görülmektedir. Modelleme konusuna 2005 yılından itibaren ilginin arttığı görülmektedir. Araştırma kapsamındaki tezler araştırma grubuna göre incelenmiş ve sonuçları Tablo 4’te sunulmuştur. 
Şafak YILDIZ | Kürşat YENILMEZ

Tablo 4. Tezlerin Araştırma Grubuna Göre Dağılımı

\begin{tabular}{lccc}
\hline \multirow{2}{*}{ Katıımcı } & Yüksek Lisans & Doktora & Toplam \\
\cline { 2 - 4 } & $f$ & $f$ & $f$ \\
\hline ilkokul & 2 & 1 & 3 \\
Ortaokul & 10 & 3 & 15 \\
Lise & 3 & 10 & 6 \\
Öğretmen Adayı & 8 & 4 & 18 \\
Öğretmen & 3 & 0 & 7 \\
Diğer & 2 & & 2 \\
\hline
\end{tabular}

*Çalışmaların bazıları birden fazla araştırma grubu içeriyor olabilir. Bu durumda çalışma grupları birden fazla kodlanmıştır.

Tablo 4 incelendiğinde en fazla araştırmanın öğretmen adayı ve ortaokul öğrencileri ile yapıldığı görülmektedir. İlkokul öğrencileri ile yapılan çalışmaların ise az sayıda olduğu görülmektedir. Yüksek lisans tezlerinde en fazla ortaokul öğrencileri üzerinde çalışma yapılırken doktora tezlerinde ise en fazla öğretmen adayları üzerinde çalışma yapılmıştır. Araştırma kapsamındaki tezler çalışmada kullanılan yönteme göre incelenmiş ve sonuçları Tablo 5'de sunulmuştur.

Tablo 5. Tezlerin Araştırmada Kullanılan Yönteme Göre Dağılımı

\begin{tabular}{lccc}
\hline \hline \multirow{2}{*}{ Kullanılan Yöntem } & Yüksek Lisans & Doktora & Toplam \\
\cline { 2 - 4 } & $f$ & $f$ & $f$ \\
\hline Nicel & 3 & 1 & 4 \\
Nitel & 13 & 12 & 25 \\
Karma & 11 & 7 & 18 \\
Belirtilmemiş & 1 & 0 & 1 \\
\hline
\end{tabular}

Tablo 5 incelendiğinde yapılan çalışmalarda en fazla nitel yöntemlerin kullanıldığı nicel yöntemlerin ise daha az tercih edildiği görülmektedir. Birçok araştırmada nicel yöntemlerin nitel yöntemlerle desteklendiği tespit edilmiştir (Kartallığlu, 2005; Kal, 2013; Dışbudak, 2014). Araştırma kapsamındaki tezler çalışmada kullanılan modele göre incelenmiş ve sonuçları Tablo 6'da sunulmuştur. 
Tablo 6. Tezlerin Araştırmada Kullanılan Modele Göre Dağılımı

\begin{tabular}{lccc}
\hline \hline & Yüksek Lisans & Doktora & Toplam \\
\cline { 2 - 4 } Kullanılan Model & $f$ & $f$ & $f$ \\
\hline Durum çalışması & 11 & 8 & 19 \\
Deneysel Desen & 11 & 8 & 19 \\
Eylem & 4 & 2 & 6 \\
Gömülü Teori & 1 & 0 & 1 \\
Etki Araştırması & 1 & 0 & 1 \\
Fenomenografik & 1 & 1 & 2 \\
Kuram Oluşturma & 0 & 1 & 1 \\
Tasarım tabanlı araş- & 1 & 0 & 1 \\
tırma yöntemi & 1 & 1 & 2 \\
Tarama & 2 & 3 & 5 \\
Belirtilmemiş & & & \\
\hline
\end{tabular}

* Çalışmaların bazıları birden fazla model içeriyor olabilir. Bu durumda çalışmanın modeli birden fazla kodlanmıştır

Tablo 6 incelendiğinde tezlerde en fazla deneysel desen ve durum çalışmaları modellerinin kullanıldığı görülmektedir. Bazı tezlerde ise kullanılan modelin belirtilmediği görülmektedir. Araştırma kapsamındaki tezler veri analiz yöntemine göre incelenmiş ve sonuçları Tablo 7'de sunulmuştur.

Tablo 7. Matematiksel Modelleme İle Illgili Tezlerin Veri Analiz Yöntemine Göre Dağılımı

\begin{tabular}{lccc}
\hline \hline \multirow{2}{*}{ Veri Analiz Yöntemi } & Yüksek Lisans & Doktora & Toplam \\
\cline { 2 - 4 } & $f$ & $f$ & $f$ \\
\hline Betimsel Analiz & 16 & 4 & 20 \\
İçerik Analizi & 8 & 7 & 15 \\
t-testi & 8 & 5 & 13 \\
Betimsel İstatistik & 4 & 3 & 7 \\
Mann-Whitney U & 3 & 2 & 5 \\
Wilcoxon İşaretli Sıralar Testi & 3 & 1 & 4 \\
\hline
\end{tabular}


Şafak YILDIZ | Kürşat YENILMEZ

\begin{tabular}{llll}
\hline Fenomenografik yöntem & 1 & 1 & 2 \\
Nitel Veri Analizi & 0 & 2 & 2 \\
$\begin{array}{l}\text { Gömülü teori (kuram oluşturma) } \\
\text { veri analizi }\end{array}$ & 1 & 2 & 3 \\
Ki-Kare Testi & 0 & 1 & 1 \\
$\quad$ Durum Odaklı ve Karşılaştırmalı & 0 & 1 & 1 \\
Durum Analizi & 0 & 1 & 1 \\
Ancova & 3 & 2 & 5 \\
Diğer & 3 & 2 & 5 \\
Belirtilmemiş & & & \\
\hline
\end{tabular}

Tablo 7 incelendiğinde tezlerde en fazla kullanılan veri analizi yönteminin betimsel analiz ve içerik analizi olduğu görülmektedir. Nicel çalışmalarda ise daha çok t-testinin kullanıldığı görülmektedir. Araştırma kapsamındaki tezler veri toplama araçlarına göre incelenmiş ve sonuçları Tablo 8 'de sunulmuştur.

Tablo 8. Tezlerin Kullanılan Veri Toplama Araçlarına Göre Dağılımı

\begin{tabular}{lccc}
\hline \hline & Yüksek Lisans & Doktora & Toplam \\
\cline { 2 - 4 } Veri Toplama Araçları & $f$ & $f$ & $f$ \\
\hline Görüşme & 19 & 14 & 33 \\
Ses / Video Kaydı & 15 & 16 & 31 \\
Test & 19 & 8 & 27 \\
$\begin{array}{l}\text { Gözlem/Araştırmacı Günlügüü-Alan } \\
\text { Notları }\end{array}$ & 8 & 14 & 22 \\
$\quad$ & & & \\
Doküman İncelemesi(Yanıt Dosya- & 11 & 8 & 19 \\
ları, Öğrenci Raporları, Düşünme Şekille- \\
ri, Görüş Formları, Bilgi Formları vb.)
\end{tabular}




\begin{tabular}{llll}
\hline Öğrenci Günlüğü & 3 & 3 & 6 \\
Grup Sunumları & 1 & 1 & 2 \\
Ders Planı & 0 & 1 & 1 \\
Belirtilmemiş & 3 & 1 & 4 \\
\hline
\end{tabular}

Tablo 8 incelendiğinde veri toplama aracı olarak en fazla görüşmenin ve ses/video kaydının kullanıldığı görülmektedir. Araştırma kapsamındaki tezler çalışılan konulara göre incelenmiş ve sonuçları Tablo 9'da sunulmuştur.

Tablo 9. Matematiksel Modelleme Ile illgili Tezlerin Çalışılan Konuya Göre Dağılımı

\begin{tabular}{|c|c|c|c|}
\hline \multirow{2}{*}{ Çalışılan Konu } & Yüksek Lisans & Doktora & Toplam \\
\hline & $f$ & $f$ & $f$ \\
\hline Modellemeye Yönelik Görüş & 6 & 1 & 7 \\
\hline Problem Çözme & 5 & 0 & 5 \\
\hline Problem Çözme ve Teknoloji & 1 & 1 & 2 \\
\hline Matematikleştirme Süreci & 1 & 0 & 1 \\
\hline İspata Yönelik Tutum & 1 & 0 & 1 \\
\hline Düşünme ve Görselleme Becerisi & 1 & 0 & 1 \\
\hline Özdeşlik (Origami ile modelleme) & 1 & 0 & 1 \\
\hline Düşünme Süreçleri & 1 & 0 & 1 \\
\hline Akademik başarı ve matematik tutumu & 1 & 0 & 1 \\
\hline Doğal Sayılar & 1 & 0 & 1 \\
\hline Öğretim programına yönelik görüş & 1 & 0 & 1 \\
\hline PISA başarı düzeyi & 1 & 0 & 1 \\
\hline Akademik Başarı ve Görüş & 1 & 0 & 1 \\
\hline $\begin{array}{l}\text { Uygulama Tasarımı Ve Tasarım Sürecini } \\
\text { Şekillendiren Müdahaleler }\end{array}$ & 1 & 0 & 1 \\
\hline Öğrenme ortamı tasarlama & 1 & 0 & 1 \\
\hline Doğrusal Denklemler & 1 & 0 & 1 \\
\hline Modelleme Becerisini Ortaya Çıkarma & 1 & 0 & 1 \\
\hline
\end{tabular}




\begin{tabular}{|c|c|c|c|}
\hline Fonksiyon & 1 & 0 & 1 \\
\hline Uygulanabilirlik & 1 & 0 & 1 \\
\hline Pedagojik Alan Bilgisi & 0 & 2 & 2 \\
\hline Matematiğin günlük yaşama uygulanması & 0 & 1 & 1 \\
\hline Matematiksel okuryazarlık ve inançları & 0 & 1 & 1 \\
\hline Öğrenme Ortamı Hazırlama & 0 & 1 & 1 \\
\hline Matematiksel İnanç & 0 & 1 & 1 \\
\hline Matematiksel Yaratıcılık & 0 & 1 & 1 \\
\hline Diziler ve seriler & 0 & 1 & 1 \\
\hline Doğrusal ilişkiler & 0 & 1 & 1 \\
\hline $\begin{array}{l}\text { Sayılar öğrenme alanına ilişkin zorluk algıSı } \\
\text { ve başarıya etki }\end{array}$ & 0 & 1 & 1 \\
\hline $\begin{array}{l}\text { Türev -akademik başarı-öz düzenleme be- } \\
\text { cerileri }\end{array}$ & 0 & 1 & 1 \\
\hline $\begin{array}{l}\text { Duyusal özellikler- problem çözme- } \\
\text { teknolojiye ilişkin düşünce }\end{array}$ & 0 & 1 & 1 \\
\hline Öğrenme öğretme uygulamaları & 0 & 1 & 1 \\
\hline Modelleme yeterliliklerinin geliştirilmesi & 0 & 1 & 1 \\
\hline Süreç İnceleme & 0 & 1 & 1 \\
\hline $\begin{array}{l}\text { Matematikleştirme Süreci ve Finansal } \\
\text { Okuryazarlık }\end{array}$ & 0 & 1 & 1 \\
\hline Teknolojinin Rolü & 0 & 1 & 1 \\
\hline
\end{tabular}

Tablo 9 incelendiğinde en fazla modellemeye yönelik görüş ve problem çözme konularında tez yazıldığı görülmektedir. Pedagojik alan bilgisi ve problem çözme-teknoloji üzerine ise 2'şer tane çalışma yapıldığı görülmektedir.

\section{Sonuç ve Öneriler}

Matematiksel modelleme ile ilgili tezlerin daha çok matematik öğretmenliği ve ilköğretim matematik öğretmenliği alanlarında yapıldığı sonucuna ulaşılmıştır. Matematikle ilgili diğer bilimlerde ise çok fazla çalışma yapılmadığı görülmektedir. Eğitim programları, fizik eğitimi, sınıf öğretmenliği gibi bölümlerde de benzer çalışmaların artması bu alana önemli katkı sağlayacaktır. 
Matematiksel modelleme ile ilgili çalışmaların 2015 ve 2016 yıllarında arttığı, 2017 yılında ise çalışma sayısının düştüğü görülmektedir. Aztekin ve Taşpınar-Şener (2015) yaptıkları çalışma sonucunda matematiksel modellemeyle ilgili çalışmaların hızla arttığını fakat yeterli düzeyde bir kapsam ve çeşitliliğe ulaşılamadığını tespit etmişlerdir. Öğretim programında önemi açıkça belirtilen matematiksel modelleme ile ilgili farklı konu alanlarında çalışmaların arttııılması önerilebilir.

Matematiksel modelleme ile ilgili çalışmaların daha çok ortaokul öğrencileri ve öğretmen adayları üzerinde yapıldığı sonucuna ulaşılmıştır. Illkokul öğrencileri, ortaöğretim öğrencileri ve öğretmenler üzerinde çok fazla çalışma yapılmadığı görülmektedir. Hâlbuki alanyazında matematiksel modelleme becerisinin ilkokul yıllarından başlanarak geliştirilmesi gerektiği ifade edilmektedir (Jones, Langrall, Thornton ve Nisbet, 2002 Akt: English ve Watters, 2004). ilkokul çağındaki çocukların belirli yeterlilikleri kazanması önemlidir. Bu yüzden ilkokul öğrencilerine yönelik daha fazla çaıışma yapılması önerilebilir. Ayrıca sistemin içerisinde olan öğretmenlerin matematiksel modelleme konusunda bilinçlenmeleri ve bu konudaki eksikliklerinin tespit edilmesi için daha fazla çalışma yapılması önerilebilir.

Çalışmalarda daha çok nitel ve karma yöntemlerin tercih edildiği sonucuna ulaşılmıştır. Çalışmalarda model olarak ise durum çalışması ve deneysel desenlerin tercih edildiği sonucuna ulaşımıştır. Karma yöntemlerde ise daha çok nicel yöntemleri desteklemek için görüşme, gözlem gibi araçların kullanıldığı tespit edilmiştir. Bu durum matematiksel modellemenin doğası gereği, katıIımcıların matematiksel modelleme sürecinin derinlemesine incelenmesi ihtiyacından kaynaklanmış olabilir. Bazı çalışmalarda kullanılan yöntemin ve modelin anlatıldığı fakat ne olduğunun söylenmediği tespit edilmiştir. Bu durum Karadağ’ın (2010) Türkiye'de yapılan doktora tezlerini incelediği çalışmasının bulguları ile paralellik göstermektedir. Aztekin ve Taşpınar-Şener (2015) yaptıkları çalışma sonucunda da çalışmaların çoğunda nitel ve karma yöntemlerin tercih edildiğini ve model olarak ise daha çok durum çalışmalarının tercih edildiğini tespit etmişlerdir. Veri analiz yöntemi olarak daha çok nitel yöntemlerden içerik analizi ve betimsel analizin tercih edildiği sonucuna ulaşıımıştır. Çalışmalarda parametrik testlerden t-testinin tercih edildiği non-parametrik testlerin fazla tercih edilmediği görülmektedir. Aztekin ve Taşpınar-Şener (2015) yaptıkları çalışma sonucunda nitel yöntemlerde veri analizi olarak daha çok betimsel analizin kullanıldığını belirlemişlerdir.

Çalışmalarda veri toplama yöntemi olarak daha çok görüşme, video/ses kaydı ve testlerin tercih edildiği sonucuna ulaşılmıştır. Anket, ölçek gibi diğer veri toplama yöntemlerinin tercih edilmediği sonucuna ulaşılmıştır.

Matematiksel modelleme ile ilgili çalışmaların en çok Dokuz Eylül Üniversitesi'nde yapıldığı sonucuna ulaşılmıştır. Ülkemizdeki üniversite sayısı göz önüne alındığında bu konuyla ilgili çalışmaların bazı üniversitelerle sınırlı kaldığı görülmektedir. Köklü üniversitelerde bile çok fazla çalışmanın yapılmadığı görülmektedir. Bu konuyla ilgili çalışmaların diğer üniversitelere yayılması ve köklü üniversitelerin bu konuyla ilgili daha fazla araştırma yapması önerilebilir.

Tezlerde en fazla modellemeye yönelik görüş ve problem çözme konularında çalışıldığı görülmektedir. Teknolojinin hakim olduğu günümüzde çok fazla çalışılmadığı görülmektedir. Modelle- 
Şafak YILDIZ | Kürşat YENILMEZ

meyle ilişkili olan gerçekçi matematik eğitimi ve uzamsal düşünme üzerine çalışmaların sınırlı olduğu görülmektedir. Matematiksel modelleme ile teknoloji, gerçekçi matematik eğitimi ve uzamsal düşünme üzerine çalışmaların yapılması önerilebilir. Ayrıca matematikteki farklı konuların matematiksel modelleme ile ilişkilendirilerek öğretimine yönelik çalışmaların yapılması da önerilebilir.

\section{Kaynaklar}

Aztekin, S. ve Şener, Z.T. (2015). Türkiye'de matematik eğitimi alanındaki matematiksel modelleme araştırmalarının içerik analizi: Bir meta-sentez çalışması. Eğitim ve Bilim, 40(178).

Bal, A. P. ve Doğanay, A. (2014). Sınıf öğretmenliği adaylarının matematiksel modelleme sürecini anlamalarını geliştirmeye yönelik bir eylem araştırması. Kuram ve Uygulamada Eğitim Bilimleri, 14(4), 1363-1384.

Blomhøj, M., \& Jensen, T.H. (2003). Developing mathematical modelling competence: Conceptual clarification and educational planning. Teaching mathematics and its applications, 22(3), 123139.

Blum, W., \& Niss, M. (1991). Applied mathematical problem solving, modelling, application, and link stoother subjects-state, trends, and issues in mathematics instruction. Educational Studies in Mathematics, 22(1), 37-68.

Budinsk, N. (2010). The positive aspects of modeling process in teaching mathematics. http://www.time2010.uma.es/Proceedings/Papers/A006 Paper.pdf adresinden 28/12/2017 tarihinde edinilmiştir.

Cheng, A.K. (2001). Teaching mathematical modelling in Singapore schools. The Mathematics Educator, 6(1). http://math.nie.edu.sg/kcang/TME paper/teachmod.html adresinden 28/12/2017 tarihinde edinilmiştir.

Crouch, R., \& Haines, C. (2004). Mathematical modelling: transitions between the real world and the mathematical model. International Journal of Mathematical Education in Science and Technology, 35(2), 197-206.

English, L.D., \& Watters, J. (2004). Mathematical modelling with young children. 28th Conference of The International Group for the Psychology of Mathematics Education, Bergen.

Eraslan, A. (2011). İlköğretim matematik öğretmen adaylarının model oluşturma etkinlikleri ve bunların matematik öğrenimine etkisi hakkındaki görüşleri. Ilköğretim Online, 10(1).

Erbaş, A. K., Kertil, M., Çetinkaya, B., Çakıroğlu, E., Alacacı, C., ve Baş, S. (2014). Matematik eğitiminde matematiksel modelleme: Temel kavramlar ve farklı yaklaşımlar. Kuram ve Uygulamada Eğitim Bilimleri, 14(4), 1-21. 
Galbraith, P. L., \& Clatworthy, N. J. (1990). Beyond Standard models meeting the challenge of modelling. Educational Studies in Mathematics, 21(2), 137-163.

Gül, Ş. ve Sözbilir, M. (2015). Fen ve matematik eğitimi alanında gerçekleştirilen ölçek geliştirme araştırmalarına yönelik tematik içerik analizi. Eğitim ve Bilim, 40(178).

Güven, B. ve Özçelik, Ç. (2017). Illkokul matematik dersine yönelik gerçekleştirilen lisansüstü eğitim tez çalışmalarına ilişkin bir inceleme. Eğitimde Kuram ve Uygulama, 13(4), 693-714.

Hıdıroğlu, Ç.N. (2012). Teknoloji destekli ortamda matematiksel modelleme problemlerinin çözüm süreçlerinin analiz edilmesi: Yaklaşım ve düşünme süreçleri üzerine bir çalışma. Yayınlanmamış Yüksek Lisans Tezi, Dokuz Eylül Üniversitesi Eğitim Bilimleri Enstitüsü, İzmir.

Karadağ, E. (2010). Eğitim bilimleri doktora tezlerinde kullanılan araştırma modelleri: nitelik düzeyleri ve analitik hata tipleri. Kuram ve Uygulamada Eğitim Yönetimi, 16(1), 49-71.

Karasar, N. (2016). Bilimsel araştırma yöntemi: Kavramlar ilkeler teknikler. Ankara: Nobel Akademik Yayıncilı.

Kayhan, M. ve Koca, S. A. Ö. (2004). Matematik eğitiminde araştırma konuları: 2000-2002. Hacettepe Üniversitesi Eğitim Fakültesi Dergisi, 26(26).

Miles, M. B., \& Huberman, A. M. (1994). Qualitative data analysis: an expanded source book. (2nd Edition). Calif. : Sage Publications

Milli Eğitim Bakanlığı [MEB]. (2013). Ortaöğretim matematik dersi öğretim programı. TTKB. Ankara: MEB Basımevi.

Özdemir, G. ve Işık, A. (2015). Katı cisimlerin alan ve hacimlerinin matematiksel model ve matematiksel modelleme yöntemiyle öğretimine yönelik öğretmen görüşleri. Kastamonu Eğitim Dergisi, 23(3), 1251-1276.

Reusser, K., \& Stebler, R. (1997). Everyword problem has a solution. The social rationality of mathematical modeling in schools. Learning and instruction, 7(4), 309-327.

Türkdoğan, A., Güler, M., Bülbül, B. Ö. ve Danişman, Ş. (2015). Türkiye'de matematik eğitiminde kavram yanılgılarıyla ilgili çalışmalar: Tematik bir inceleme. Mersin Üniversitesi Eğitim Fakültesi Dergisi, 11(2).

Ural, A. ve Ülper, H. (2013). Illköğretim matematik öğretmeni adaylarının matematiksel modelleme ile okuduğunu anlama becerileri arasındaki ilişkinin değerlendirilmesi. Kuramsal Eğitimbilim Dergisi, 6(2), 214-241.

Yalçınkaya, Y. ve Özkan, H. H. (2012). 2000-2011 Yılları arasında eğitim fakülteleri dergilerinde yayımlanan matematik öğretimi alternatif yöntemleri ile ilgili makalelerin içerik analizi. Süleyman Demirel Üniversitesi Sosyal Bilimler Enstitüsü Dergisi, 16, 31-45. 
Şafak YILDIZ | Kürşat YENILMEZ

Yaşar, Ş. ve Papatğa, E. (2015). illkokul matematik derslerine yönelik yapılan lisansüstü tezlerin incelenmesi. Trakya Üniversitesi Eğitim Fakültesi Dergisi, 5(2).

Yenilmez, K. ve Sölpük, N. (2014). Matematik dersi öğretim programı ile ilgili tezlerin incelenmesi (2004-2013). Eğitim ve Öğretim Araştırmaları Dergisi,3 (2), 33-42.

Yıldırım, A. ve Şimşek, H. (2006). Sosyal bilimlerde nitel araştırma yöntemleri, (5. Baskı), Ankara: Seçkin Yayıncılık.

Yücedağ, T. (2010). 2000-2009 yılları arasında matematik eğitimi alanında Türkiye'de yapılan çalışmalarının bazı değişkenlere göre incelenmesi. Yayınlanmamış doktora tezi, Selçuk Üniversitesi eğitim bilimleri enstitüsü.

\section{Ek 1: Araştırmada İncelenen Tezler}

Aydın, H. (2008). İngiltere'de öğrenim gören öğrencilerin ve öğretmenlerin matematiksel modelleme kullanımına yönelik fenomenografik bir çalışma. Yayınlanmamış yüksek lisans tezi, Gazi üniversitesi eğitim bilimleri enstitüsü.

Aydın Güç, F. (2015). Matematiksel modelleme yeterliklerinin geliştirilmesine yönelik tasarlanan öğrenme ortamlarında öğretmen adaylarının matematiksel modelleme yeterliklerinin değerlendirilmesi. Yayınlanmamış Doktora Tezi, Karadeniz Teknik Üniversitesi Eğitim Bilimleri Enstitüsü, Trabzon.

Aydoğan Yenmez, A. (2012). Ortaöğretim matematik öğretmenlerinin pedagojik alan ve pedagojik bilgilerindeki gelişimin, modelleme yaklaşımına göre tasarlanmış bir mesleki gelişim ve eğitim etkinliği sürecinde incelenmesi. Yayınlanmamış Doktora Tezi, Ortadoğu Teknik Üniversitesi Fen Bilimleri Enstitüsü, Ankara.

Bakırcı, C. (2016). Matematiksel modelleme etkinliklerinin ortaokul öğrencilerinin pisa matematik başarı düzeylerine etkisi. Yayınlanmamış Yüksek Lisans Tezi, Gazi Üniversitesi Eğitim Bilimleri Enstitüsü, Ankara.

Başkan, Z. (2011). Doğrusal ve düzlemde hareket ünitelerinin matematiksel modelleme kullanılarak öğretiminin öğretmen adaylarının öğrenmelerine etkileri. Yayınlanmamış Doktora Tezi, Karadeniz Teknik Üniversitesi Eğitim Bilimleri Enstitüsü, Trabzon.

Bilen, N. (2015). Ortaokul matematik dersi beşinci sınıf öğretim programı́nın öğretmen görüşlerine göre matematiksel model ve modelleme açısından incelenmesi. Yayınlanmamış Yüksek Lisans Tezi, Atatürk Üniversitesi Eğitim Bilimleri Enstitüsü, Erzurum. 
Cinislioğlu, B. (2017). Matematiksel modelleme yöntemi ile doğrusal denklemler konusunun öğretiminin ortaokul üçüncü sınıf öğrencilerinin akademik başarısına etkisi. Yayınlanmamış Yüksek Lisans Tezi, Atatürk Üniversitesi Eğitim Bilimleri Enstitüsü, Erzurum.

Çarman, Ş. (2007). Kara Harp Okulu'nda türev ve integral kavramlarının mesleğe yönelik modellemeleri ve bunlar hakkında öğretim elemanı ve Harbiyeli görüşleri üzerine fenomenografik çalışma. Yayınlanmamış Yüksek Lisans Tezi, Gazi Üniversitesi Eğitim Bilimleri Enstitüsü, Ankara.

Çavuşoğlu, N. (2016). Ortaokul matematik öğretmenlerinin matematik uygulamaları dersinde matematiksel modelleme hakkında görüşlerinin incelenmesi. Yayınlanmamış Yüksek Lisans Tezi, Dokuz Eylül Üniversitesi Eğitim Bilimleri Enstitüsü, İzmir.

Çelikkol, Ö. (2016). 7. sınıf öğrencilerine cebirsel sözel problemlerde matematiksel modelleme uygulaması: bir eylem araştırması. Yayınlanmamış yüksek lisans tezi. Osmangazi Üniversitesi, Eskişehir, Türkiye.

Çetinkaya, U. (2014). Üniversitelerdeki matematiksel modelleme uygulamalarının lise matematik ve geometri dersleri için yapılabilirliği ve bir uygulama. Yayınlanmamış Yüksek Lisans Tezi, Gediz Üniversitesi Fen Bilimleri Enstitüsü, İzmir.

Çiltaş. A. (2011). Dizi ve seriler konusunun matematiksel modelleme yoluyla öğretiminin ilköğretim matematik öğretmeni adaylarının öğrenme ve modelleme becerileri üzerine etkisi. Yayınlanmamış Doktora Tezi, Atatürk Üniversitesi Eğitim Bilimleri Enstitüsü, Erzurum.

Dışbudak, K. (2014). Model oluşturma etkinliklerinin 6.sınıf öğrencilerinin akademik başarılarına ve matematiğe karşı tutumlarına etkisi. Yayınlanmamış Yüksek Lisans Tezi, Gazi Üniversitesi Eğitim Bilimleri Enstitüsü, Ankara.

Doruk, B.K. (2010). Matematiği günlük yaşama transfer etmede matematiksel modellemenin etkisi. Yayınlanmamış Doktora Tezi, Hacettepe Üniversitesi Sosyal Bilimler Enstitüsü, Ankara.

Erol, M. (2015). Modelleme etkinliklerinin 9.sınıf öğrencilerinin matematiksel okuryazarlıkları ve inançları üzerine etkisi. Yayınlanmamış Doktora Tezi, Balıkesir Üniversitesi Fen Bilimleri Enstitüsü, Balıkesir.

Güder, Y. (2013). Ortaokul matematik öğretmenlerinin matematiksel modellemeye ilişkin görüşleri. Yayınlanmamış Yüksek Lisans Tezi. Fırat Üniversitesi Eğitim Bilimleri Enstitüsü, Elazığ.

Hıdıroğlu, Ç.N. (2012). Teknoloji destekli ortamda matematiksel modelleme problemlerinin çözüm süreçlerinin analiz edilmesi: Yaklaşım ve düşünme süreçleri üzerine bir çalışma. Yayınlanmamış Yüksek Lisans Tezi, Dokuz Eylül Üniversitesi Eğitim Bilimleri Enstitüsü, İzmir.

Hıdıroğlu, Ç.N. (2015). Teknoloji destekli ortamda matematiksel modelleme problemlerinin çözüm süreçlerinin analizi: bilişsel ve üst bilişsel yapılar üzerine bir açıklama. Yayınlanmamış Doktora Tezi, Dokuz Eylül Üniversitesi Eğitim Bilimleri Enstitüsü, İzmir. 
Şafak YILDIZ | Kürşat YENILMEZ

Işık, N. (2016). Matematiksel modelleme etkinliklerinin ilkokul 4. sınıfta sayılar öğrenme alanına ilişkin zorluk algısı ve başarıya etkisi. Yayınlanmamış Doktora Tezi, Necmettin Erbakan Üniversitesi Eğitim Bilimleri Enstitüsü, Konya.

Kal, F. M. (2013). Matematiksel modelleme etkinliklerinin ilköğretim 6. sınıf öğrencilerinin matematik problemi çözme tutumlarına etkisi. Yayınlanmamış Yüksek Lisans Tezi. Kocaeli Üniversitesi Fen Bilimleri Enstitüsü, Kocaeli.

Kandemir, M.A. (2011). Modelleme etkinliklerinin öğrencilerin duyuşsal özelliklerine problem çözme ve teknolojiye ilişkin düşüncelerine etkisinin incelenmesi. Yayınlanmamış Doktora Tezi, Balıkesir Üniversitesi Fen Bilimleri Enstitüsü, Balıkesir

Karabaş, C. (2016). Illköğretim matematik öğretmen adaylarının doğrusal ilişkileri modelleme süreçlerinin ve bilişsel yeterliklerinin incelenmesi. Yayınlanmamış Doktora Tezi, Anadolu Üniversitesi Eğitim Bilimleri Enstitüsü, Eskişehir.

Karabörk, M.A. (2016). Model oluşturma etkinliklerinin 7. Sınıf öğrencilerinin matematik dersi başarılarına etkisi ve öğrencilerin etkinliklere yönelik görüşleri. Yayınlanmamış Yüksek Lisans Tezi, Abant i̇zzet Baysal Üniversitesi Eğitim Bilimleri Enstitüsü, Bolu.

Karacı, G. (2016). İlköğretim matematik öğretmen adaylarının matematiksel modelleme becerilerinin geliştirilmesine yönelik öğrenme ortamının hazırlanması ve değerlendirilmesi. Yayınlanmamış Yüksek Lisans Tezi, Bülent Ecevit Üniversitesi Fen Bilimleri Enstitüsü, Zonguldak.

Karalı, D. (2013). Illköğretim matematik öğretmen adaylarının matematiksel modelleme hakkındaki görüşlerinin ortaya çıkarılması. Yayınlanmamış Yüksek Lisans Tezi, Abant izzet Baysal Üniversitesi Eğitim Bilimleri Enstitüsü, Bolu.

Kartallığlu, S. (2005). ilköğretim 3. ve 4. Sınıf öğrencilerinin sözel matematik problemlerini modellemesi: çarpma ve bölme işlemi. Yayınlanmış Yüksek Lisans Tezi, Abant izzet Baysal Üniversitesi Sosyal Bilimler Enstitüsü, Bolu.

Kertil, M. (2008). Matematik öğretmen adaylarının problem çözme becerilerinin modelleme sürecinde incelenmesi. Yayınlanmamış yüksek lisans tezi, Marmara Üniversitesi Eğitim Bilimleri Enstitüsü.

Kol, M. (2014). Illköğretim matematik öğretmen adaylarının matematikselleştirme sürecinin bir matematiksel modelleme etkinliği süresince incelenmesi. Yayınlanmamış Yüksek Lisans Tezi, Ortadoğu Teknik Üniversitesi Fen Bilimleri Enstitüsü, Ankara.

Korkmaz, H. (2014). Ortaöğretim matematik öğretmen adaylarının matematiksel modelleme ve modelleme pedagojisi üzerine düşüncelerinin bir modelleme dersi süresince incelenmesi. Yayınlanmamış Doktora Tezi, Ortadoğu Teknik Üniversitesi Fen Bilimleri Enstitüsü, Ankara. 
Koylahisar Dündar, T. (2012). İlköğretim 8. sınıf öğrencilerinde özdeşlikleri modelleme becerilerinin incelenmesi: Origami ile modellenmesi. Yayınlanmamış Yüksek Lisans Tezi, Ondokuz Mayıs Üniversitesi Eğitim Bilimleri Enstitüsü, Samsun.

Muşlu, M. (2016). Doğal sayılarda işlemler konusunun öğretiminde matematiksel modelleme yönteminin öğrenci başarısına etkisi. Yayınlanmamış Yüksek Lisans Tezi, Atatürk Üniversitesi Eğitim Bilimleri Enstitüsü, Erzurum.

Ören Vural, D. (2015). Matematiksel modelleme temelli bir meslek gelişim programı boyunca ortaöğretim matematik öğretmenlerinin matematikle ilgili inançları. Yayınlanmamış Doktora Tezi, Ortadoğu Teknik Üniversitesi Fen Bilimleri Enstitüsü, Ankara.

Özcan, F. M. (2005). Illköğretim 2. kademede 6-7-8. sınıf öğrencilerinin problem çözme stratejileri ve matematiksel modellemenin problem çözmedeki yeri ve önemi. Yayınlanmamış Yüksek Lisans Tezi, Dokuz Eylül Üniversitesi Eğitim Bilimleri Enstitüsü, İzmir.

Özdemir, E. (2014). Matematik eğitiminde modelleme üzerine öğrenme-öğretme uygulamaları. Yayınlanmamış Doktora Tezi, Balıkesir Üniversitesi Fen Bilimleri Enstitüsü, Balıkesir.

Özer, A. Ö. (2016). Ortaöğretim öğrencilerine yönelik matematiksel modellemeye dayalı bir uygulama tasarımı ve tasarım sürecini şekillendiren müdahaleler. Yayınlanmamış Yüksek Lisans Tezi, Dokuz Eylül Üniversitesi Eğitim Bilimleri Enstitüsü, İzmir.

Özturan Sağırlı, M. (2010). Türev konusunda matematiksel modelleme yönteminin ortaöğretim öğrencilerinin akademik başarıları ve öz-düzenleme becerilerine etkisi. Yayınlanmamış Doktora Tezi, Atatürk Üniversitesi Eğitim Bilimleri Enstitüsü, Erzurum.

Pala, G. (2015). 8. sınıf öğrencilerinin matematiksel modelleme hakkındaki görüşlerinin belirlenmesi üzerine nitel bir araştırma. Yayınlanmamış Yüksek Lisans Tezi, Fırat Üniversitesi Eğitim Bilimleri Enstitüsü, Elazığ.

Saka, E. (2016). Öğretmen adaylarının matematiksel modelleme problemlerini çözme sürecinde teknolojinin rolü. Yayınlanmamış Doktora Tezi, Karadeniz Teknik Üniversitesi Eğitim Bilimleri Enstitüsü, Trabzon.

Şahin, N. (2014). Illkokul 4. sınıf öğrencilerinin model oluşturma etkinlikleri üzerindeki düşünme süreçleri. Yayınlanmamış Yüksek lisans tezi. Ondokuz Mayıs Üniversitesi Eğitim Bilimleri Enstitüsü, Samsun.

Şandır, H. (2010). Matematik öğretmen ve öğretmen adaylarının tasarladıkları ve uyguladıkları modellemelere ait süreçlerin incelenmesi. Yayınlanmamış Doktora Tezi, Gazi Üniversitesi Eğitim Bilimleri Enstitüsü, Ankara.

Şen Zeytun, A. (2013). Öğretmen adaylarının matematiksel modelleme süreçlerinin ve bu sürece etki eden faktörlere ilişkin görüşlerinin incelenmesi. Yayınlanmamış Doktora Tezi, Ortadoğu Teknik Üniversitesi Fen Bilimleri Enstitüsü, Ankara. 
Şafak YILDIZ | Kürşat YENILMEZ

Şengil Akar, Ş. (2017). Üstün yetenekli öğrencilerin matematiksel yaratıcılıklarının matematiksel modelleme etkinlikleri sürecinde incelenmesi. Yayınlanmamış Doktora Tezi, Hacettepe Üniversitesi Eğitim Bilimleri Enstitüsü, Ankara.

Ünveren, E.N. (2010). İlköğretim matematik öğretmen adaylarının ispata yönelik tutumlarının matematiksel modelleme sürecinde incelenmesi. Yayınlanmamış yüksek lisans tezi, Balıkesir Üniversitesi Fen Bilimleri Enstitüsü, Balıkesir.

Taşova, H.i. (2011). Matematik öğretmen adaylarının modelleme etkinlikleri ve performansı sürecinde düşünme ve görselleme becerilerinin incelenmesi. Yayımlanmamış Yüksek Lisans Tezi, Marmara Üniversitesi, Eğitim Bilimleri Enstitüsü, İstanbul.

Tekin Dede, A. (2015). Matematik derslerinde öğrencilerin modelleme yeterliliklerinin geliştirilmesi: Bir eylem araştırması. Yayınlanmamış Doktora Tezi, Dokuz Eylül Üniversitesi Eğitim Bilimleri Enstitüsü, İzmir.

Tural Sönmez, M. (2016). Yedinci sınıf öğrencilerinin matematiksel modelleme etkinlikleriyle matematikselleştirme süreçlerinin ve finansal okuryazarlıklarının incelenmesi. Yayınlanmamış Doktora Tezi, Hacettepe Üniversitesi Eğitim Bilimleri Enstitüsü, Ankara.

Yanbıyık, S. (2016). Sınıf öğretmeni adaylarının matematiksel modelleme becerileri: Fermi problemleri uygulamaları. Yayınlanmamış Yüksek Lisans Tezi, Gaziosmanpaşa Üniversitesi Eğitim Bilimleri Enstitüsü, İzmir.

Yazır, F. (2015). Modelleme temelli yapılan öğretimin 9. sınıf fonksiyonlar konusunda kavramsal ve işlemsel bilgiye etkisi. Yayınlanmamış Yüksek Lisans Tezi, Marmara Üniversitesi Eğitim Bilimleri Enstitüsü, İstanbul. 